\title{
UTILIZATION OF LIQUID SMOKE FROM OIL PALM KERNEL SHELL TO PRESERVE MACKEREL
}

\author{
M. Faisal ${ }^{1, *}$, Asri Gani ${ }^{1}$ and Husni ${ }^{2}$ \\ ${ }^{1}$ Department of Chemical Engineering, Syiah Kuala University, Banda Aceh, 23111, Indonesia \\ ${ }^{2}$ Department of Agro Technology, Syiah Kuala University, Banda Aceh, 23111, Indonesia \\ *E-mail : mfaisal@unsyiah.ac.id
}

\begin{abstract}
Oil palm kernel shell is a waste product of palm oil manufacturing and contains significant amounts of several chemical compounds including cellulose, hemicelluloses, and lignin. Pyrolysis of these compounds results in good quality liquid smoke. The aim of this research was to utilize this liquid smoke to preserve mackerel. The liquid smoke in this research was obtained by pyrolyzing oil palm kernel shell at temperatures ranging from $300-380^{\circ} \mathrm{C}$. The resulting liquid smoke was then distilled at $200^{\circ} \mathrm{C}$, and its chemical composition was analyzed using gas chromatography-mass spectrometry. The liquid smoke was then used to preserve mackerel at a variety of concentrations, including $0.5 \%, 1 \%, 2 \%$, and $3 \%$. The efficacy of preserving the mackerel using liquid smoke was assessed through TVB (total volatile base) analysis and organoleptic testing. TVB testing showed that mackerel remained fresh for up to 64 hours after being treated with $2 \%$ and 3\% liquid smoke at a pyrolysis temperature of $380^{\circ} \mathrm{C}$, with TVB values of $26.733 \mathrm{mgN}$ and $24.974 \mathrm{mgN}$, respectively. The organoleptic testing showed that at a liquid smoke concentration of $3 \%$ and a pyrolysis temperature of $380^{\circ} \mathrm{C}$, mackerel can remain fresh for up to 48 hours, with acceptable color and texture, and is suitable for consumption. Meanwhile, the non-preserved (control) mackerel had already deteriorated within 24 hours in terms of color, texture, and smell.
\end{abstract}

Keywords: Oil palm kernel shell, liquid smoke, preservation, pyrolysis, GC-MS, TVB.

(C) RASĀYAN. All rights reserved

\section{INTRODUCTION}

Food preservation is important for prolonging the shelf life of food to minimize microbial and oxidative deterioration. Formalin is a widely used food preservative that contains about $37 \%(\mathrm{w} / \mathrm{w})$ formaldehyde in water, which is the active component in this preservative ${ }^{1}$. However, this preservative is dangerous for humans; it has a strong odor, and contact with the eyes and skin can cause irritation. Another widely used preservative is borax, a hydrate that is highly water soluble; accumulation of this compound in human bodies can damage the immune system. Because of these dangerous effects, natural preservatives that are safe for human consumption need to be developed. One alternative is liquid smoke from oil palm kernel shell.

Oil palm kernel shells mainly comprise hemicelluloses, cellulose, and lignin. Pyrolysis of hemicelluloses results in furfural, furan and its derivatives, acetic acid, and carboxylic acids. The most important result of cellulose pyrolysis is the production of small amounts of acetic acid and phenol, whereas lignin pyrolysis results in the development of the aroma of smoked products. These aromatic compounds originate from phenol derivatives such as guaiacol (2-methoxyphenol), syringol (1,6-dimethoxyphenol), and their derivatives $^{2}$. These phenols and organic acids are bacteriostatic, and can, therefore, be used as natural food preservatives.

Mackerel is a popular food because of its nutritional benefits. It is high in protein and $\omega-3$ fatty acids, especially eicosapentaenoic acid and docosahexaenoic acid ${ }^{3}$, and therefore, the consumption of mackerel provides many health benefits. However, the shelf life of this fish and its food products is generally short, and chemical and physical treatment are required to prolong their shelf life. Several studies have shown various methods to prolong the shelf life of mackerel, such as using lactic acid ${ }^{4}$, a combination of sodium

Rasayan J. Chem., 11(3), 1120 - 1125(2018)

http://dx.doi.org/10.31788/RJC.2018.1132090

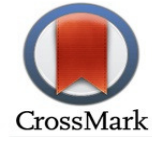


chloride and clove ${ }^{5}$, mint (Mentha arvensis) leaf and citrus (Citrus aurantium) peel extracts ${ }^{6}$, salting and smoking $^{7}$, potassium lactate ${ }^{8}$, and rosemary extract combined with vacuum packing ${ }^{9}$. Liquid smoke from oil palm kernel shell biomass is another alternative because of its antibacterial and antioxidant properties. Liquid smoke from various types of biomass has been used as mouthwash ${ }^{10}$, flavoring ${ }^{11-14}$, tuna preservative $^{15}$, and meatball preservative ${ }^{16}$. The aim of the present research was to test the efficacy of liquid smoke from the pyrolysis of oil palm kernel shell to preserve mackerel through TVB testing and sensory analysis.

\section{EXPERIMENTAL}

About $5 \mathrm{~kg}$ of oil palm kernel shell was put in a homemade pyrolysis reactor (stainless steel; $32 \mathrm{~cm}$ in diameter and $50 \mathrm{~cm}$ in height), and pyrolysis was carried out at temperatures of $300^{\circ} \mathrm{C}, 340^{\circ} \mathrm{C}$, and $380^{\circ} \mathrm{C}$, respectively. The resulting smoke was condensed into Grade 3 liquid smoke, tar, and charcoal following the methodology from previous research ${ }^{17-20}$. This liquid smoke was then analyzed using gas chromatography-mass spectrometry (GC-MS) based on the method developed by Guillen and Ibargoitia ${ }^{11}$, and then distilled at $180-200^{\circ} \mathrm{C}$ to separate the liquid smoke from the tar, thus producing Grade 1 liquid smoke. Preservation was carried out by soaking fresh mackerel in the liquid smoke at concentrations of $0.5 \%, 1 \%, 2 \%$, and $3 \%$, respectively. The acceptable storage duration of the fish samples was then assessed by organoleptic and TVB testing every 8 hours.

\section{TVB Testing}

\section{RESULTS AND DISCUSSION}

TVB testing is a method used to measure the freshness of fish or other foods against the decaying process caused by microorganisms as a result of the loss of fat or protein ${ }^{21}$. Figure 1 shows the effect of the pyrolysis temperature and liquid smoke concentration on the TVB values.

The TVB results from mackerel soaked in liquid smoke for 72 hours at temperatures of $300^{\circ} \mathrm{C}, 340^{\circ} \mathrm{C}$, and $380^{\circ} \mathrm{C}$, at liquid smoke concentrations of $1 \%, 2 \%$, and $3 \%$, showed that the pyrolysis temperature influences the TVB values. The changes in the TVB values did not always directly correspond to the phenol concentration, possibly because other carboxylates also play significant roles in preservation. At a liquid smoke concentration of $0.5 \%$, the resulting TVB values only changed slightly as the temperature increased. At $300^{\circ} \mathrm{C}$, the acetic acid, and phenol content were relatively high compared to the contents at $340^{\circ} \mathrm{C}$ and $380^{\circ} \mathrm{C}$. A lower concentration of liquid smoke did not decrease the TVB values and therefore, the concentration of liquid smoke does not appear to affect the level of preservation. Figure 2 shows the effect of the liquid smoke concentration on the TVB values over the storage time in mackerel that underwent pyrolysis at a temperature of $340^{\circ} \mathrm{C}$.

There are four categories of TVB values, including (1) up to $10 \mathrm{mg} \mathrm{N} / 100 \mathrm{~g}$, meaning that the fish is very fresh; (2) 10 to $20 \mathrm{mg} \mathrm{N} / 100 \mathrm{~g}$, meaning that the fish is fresh; (3) 20 to $30 \mathrm{mg} \mathrm{N} / 100 \mathrm{~g}$, meaning that the fish is at its consumable freshness threshold, but has relatively low appeal in terms of its color and smell; and (4) more than $30 \mathrm{mg} \mathrm{N} / 100 \mathrm{~g}$, meaning that the fish has an unacceptable taste and smell, and should not be consumed ${ }^{22}$.

Liquid smoke at a pyrolysis temperature of $340^{\circ} \mathrm{C}$, at $0.5 \%$ liquid smoke concentration, and stored for 72 hours resulted in the highest TVB value, at $35.87 \mathrm{mgN}$. In this condition, the fish is rotten, and should not be consumed. Thus, lower liquid smoke concentration and longer storage time contribute to faster decay and the development of an unacceptable smell. These outcomes are caused by protein degradation and the presence of decaying microbes, resulting in increased levels of nitrogenous bases that easily vaporize such as mono, trimethylamine, and dimethylamine ${ }^{23}$.

The preservation duration depends on the liquid smoke concentration; the higher the concentration, the better preserved the fish, because the protein degradation is minimized, thus inhibiting the growth of microorganisms in the mackerel. After being treated with liquid smoke at $2 \%$ concentration, the mackerel had a TVB value of $29.54 \mathrm{mgN}$, which means that it is still suitable for consumption. The non-preserved mackerel (control) had the shortest shelf life, with a TVB value of $30.92 \mathrm{mgN}$ after 32 hours. A TVB value of more than $30.00 \mathrm{mgN}$ means that the fish has lost its freshness and is more firm, with a change in color to white or cream and an unacceptable smell, and therefore, should not be consumed. 
RASĀYAN J. Chem.

Vol. 11 | No. 3 |1120 - 1125 | July - September | 2018

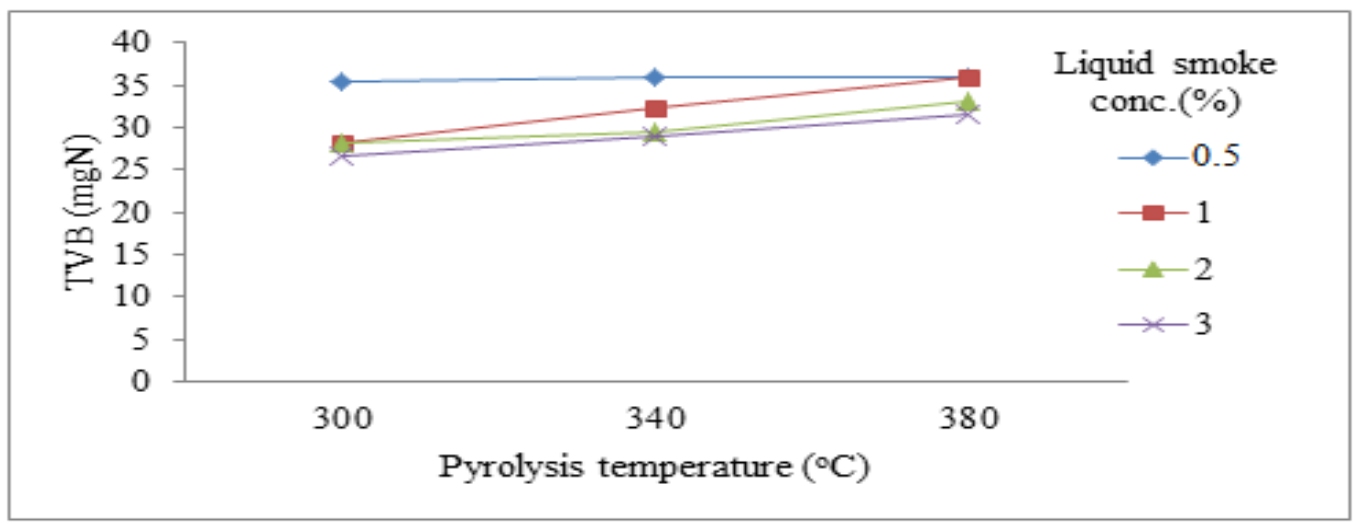

Fig.-1: Relationship between the TVB value and pyrolysis temperature of oil palm kernel shells (72 hours of preservation)

The ambient temperature that the test was carried out at was conducive to microbial growth, and no antimicrobials were added to inhibit this growth. The fish preserved for 32 hours at a liquid smoke concentration of $0.5 \%$ and a pyrolysis temperature of $340^{\circ} \mathrm{C}$ was still suitable for consumption, and appeared fresh, with a TVB value of $17.93 \mathrm{mgN}$.

\section{Organoleptic Testing}

Organoleptic testing is based on the senses, and is used to assess the color, smell, taste, and texture of food products. This test involved 12 panelists, whose reactions can be approaching or avoiding. The aim of this test was to determine the acceptability of the liquid smoke-preserved mackerel after being stored for certain lengths of time.

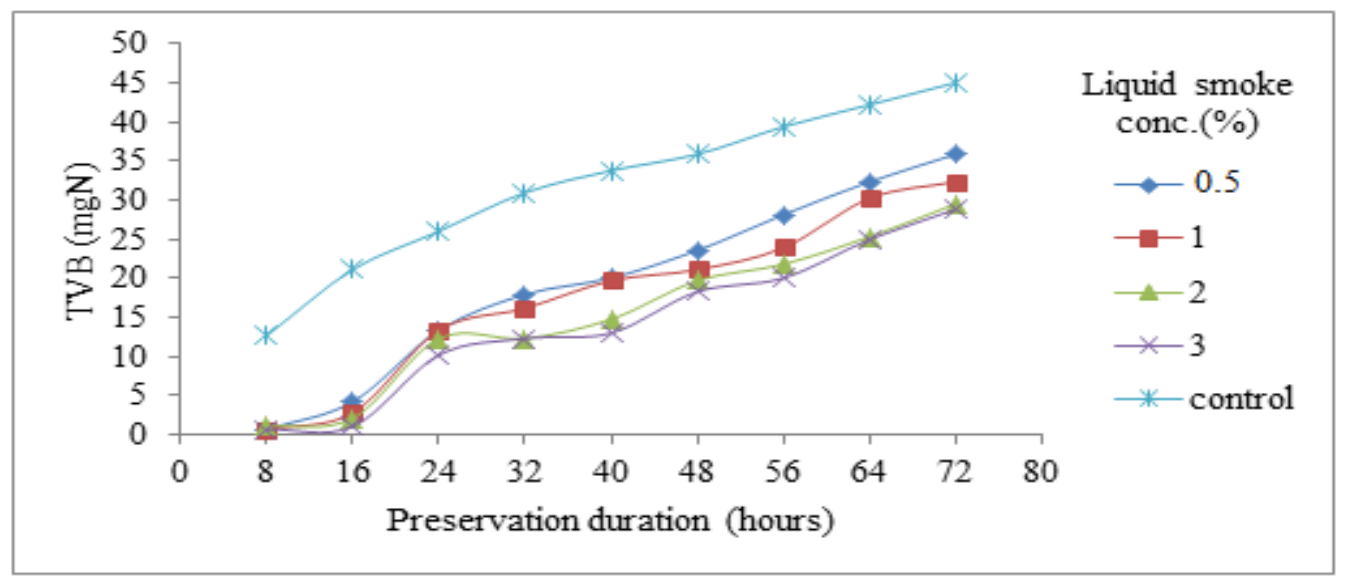

Fig.-2: Results of the TVB testing in mackerel over the storage time at a pyrolysis temperature of $340^{\circ} \mathrm{C}$

\section{Color}

Color is an organoleptic test parameter that is important for assessing food quality, because it is the first parameter that determines consumers' acceptance of a product. The color of a food product can attract consumers to it, and also provides insights into the chemical changes occurring within the food. The freshness of mackerel can be ascertained from its grayish-black skin and pinkish meat that still contains blood. Table 1 shows the results of the color testing over the storage time.

Table-1 shows that mackerel preserved at various concentrations of liquid smoke differed in color depending on the soaking duration. After 64 hours of soaking in 3\% liquid smoke at a pyrolysis temperature of $380^{\circ} \mathrm{C}$, the color was cream, and therefore, the fish was deemed to be acceptable. A food product with high-quality nutrition, good taste, and interesting texture will be less attractive to consumers if its color is unappealing. Consumers are more attracted to food products that have normal coloring. 
At a pyrolysis temperature of $380^{\circ} \mathrm{C}$ and liquid smoke concentration of $0.5 \%$, after 24 hours, the fish was still white in color and after 40 hours at 3\% concentration, the fish was still deemed to be fresh as assessed by this method. The higher the concentration of the liquid smoke, the longer it took for the fish to change color. Without the addition of a preservative, the fish color changed to cream after 24 hours.

Table-1: Results of the Organoleptic Test in Mackerel (Color)

\begin{tabular}{|c|c|c|c|c|c|c|c|c|c|c|}
\hline \multirow{2}{*}{$\begin{array}{c}\text { Pyrolysis } \\
\text { Temperature } \\
\left({ }^{\circ} \mathrm{C}\right)\end{array}$} & \multirow{2}{*}{$\begin{array}{c}\text { Liquid } \\
\text { Smoke } \\
\text { Conc. }(\%)\end{array}$} & \multicolumn{9}{|c|}{ Color Change (hours) } \\
\hline & & 8 & 16 & 24 & 32 & 40 & 48 & 56 & 64 & 72 \\
\hline \multirow{4}{*}{300} & 0.5 & 5 & 5 & 5 & 4 & 4 & 3 & 3 & 2 & 1 \\
\hline & 1 & 5 & 5 & 5 & 4 & 4 & 3 & 3 & 2 & 1 \\
\hline & 2 & 5 & 5 & 5 & 5 & 4 & 3 & 2 & 2 & 1 \\
\hline & 3 & 5 & 5 & 5 & 5 & 4 & 4 & 3 & 3 & 2 \\
\hline \multirow{4}{*}{340} & 0.5 & 5 & 5 & 5 & 4 & 3 & 3 & 3 & 2 & 1 \\
\hline & 1 & 5 & 5 & 5 & 4 & 4 & 3 & 3 & 2 & 2 \\
\hline & 2 & 5 & 5 & 5 & 5 & 4 & 4 & 3 & 2 & 2 \\
\hline & 3 & 5 & 5 & 5 & 5 & 4 & 4 & 4 & 3 & 2 \\
\hline \multirow{4}{*}{380} & 0.5 & 5 & 5 & 5 & 4 & 4 & 3 & 3 & 2 & 2 \\
\hline & 1 & 5 & 5 & 5 & 4 & 4 & 3 & 3 & 3 & 2 \\
\hline & 2 & 5 & 5 & 5 & 5 & 5 & 4 & 4 & 3 & 2 \\
\hline & 3 & 5 & 5 & 5 & 5 & 5 & 4 & 4 & 4 & 3 \\
\hline
\end{tabular}

Note: 1. Brown, 2. Light brown, 3. Cream, 4. Light cream, 5. White

\section{Taste and Smell}

Aroma is the result of the response of the nose to the distinct vapors of a food product. Taste and smell testing are very important in the food industry and enable consumers to directly assess the food. Tables- 2 and 3 show that high concentrations of liquid smoke can slow down the development of unpleasant changes in smell and taste in mackerel, thereby preserving it for up to 64 hours. After 72 hours, the fish preserved using $3 \%$ liquid smoke and at a pyrolysis temperature of $380^{\circ}$, $\mathrm{C}$ was judged to have unacceptable taste and smell. The smoky aroma in the mackerel occurs from the absorption of the liquid smoke into the fish skin. The smell worsens with the loss of acetic acid, which indicates product damage caused by oxidation. Tables- 3 and 4 show that the fish still had acceptable taste and smell, and was still considered to be suitable for consumption after 48 hours under any of the test conditions. Without a preservative, the fish developed an unpleasant smell and taste within 24 hours. The distinct taste and smell were due to the radical autoxidation of non-saturated fatty acids with oxidized fat. During storage, oxidation continues, resulting in the production of peroxide and hydroperoxide, which are broken down into compounds that result in an unpleasant smell and taste.

\section{Texture}

The texture testing was carried out using the hands and mouth. Table- 4 shows that the texture remains acceptable for up to 48 hours at a liquid smoke concentration of $3 \%$ and at a pyrolysis temperature of $380^{\circ} \mathrm{C}$. The changes in texture are influenced by the speed of bacterial growth. The results showed that at 32 hours, the texture was still chewy and that the texture became chewier after 64 hours (at a liquid smoke concentration of $3 \%$ and a pyrolysis temperature of $380^{\circ} \mathrm{C}$ ). Around $80 \%$ of the panelists preferred the 'quite chewy' texture, and only $20 \%$ of the panelists preferred the 'very chewy' texture. Consumers generally prefer a relatively chewy texture because a very chewy texture may indicate the use of dangerous preservatives ${ }^{24}$.

\begin{tabular}{c|c|c|c|c|c|c|c|c|c|c}
\multicolumn{10}{c}{ Table-2: Results of Organoleptic Test on Mackerel (Taste) } \\
\hline $\begin{array}{c}\text { Pyrolysis } \\
\text { Temperature } \\
\left({ }^{\circ} \mathrm{C}\right)\end{array}$ & $\begin{array}{c}\text { Liquid } \\
\text { Smoke } \\
\text { Conc. }(\%)\end{array}$ & 8 & 16 & 24 & 32 & 40 & 48 & 56 & 64 & 72 \\
\cline { 3 - 14 } & 0.5 & 5 & 5 & 4 & 4 & 4 & 3 & 2 & 1 & 1 \\
\cline { 2 - 14 } 300 & 1 & 5 & 5 & 4 & 4 & 4 & 3 & 2 & 2 & 1 \\
\cline { 2 - 13 } & 2 & 5 & 5 & 5 & 4 & 4 & 3 & 3 & 2 & 1 \\
\hline
\end{tabular}


RASĀYAN J. Chem.

Vol. 11 | No. 3 |1120 - 1125 | July - September | 2018

\begin{tabular}{l|c|c|c|c|c|c|c|c|c|c}
\hline & 3 & 5 & 5 & 5 & 4 & 4 & 3 & 3 & 2 & 2 \\
\hline \multirow{3}{*}{340} & 0.5 & 5 & 5 & 4 & 3 & 3 & 3 & 2 & 1 & 1 \\
\cline { 2 - 11 } & 1 & 5 & 5 & 4 & 3 & 3 & 3 & 2 & 2 & 1 \\
\cline { 2 - 11 } & 2 & 5 & 5 & 5 & 3 & 3 & 3 & 3 & 2 & 1 \\
\hline \multirow{3}{*}{380} & 0.5 & 5 & 5 & 5 & 3 & 3 & 3 & 2 & 2 & 1 \\
\cline { 2 - 11 } & 1 & 5 & 5 & 5 & 4 & 4 & 3 & 2 & 2 & 1 \\
\cline { 2 - 11 } & 2 & 5 & 5 & 5 & 4 & 4 & 4 & 3 & 2 & 1 \\
\cline { 2 - 11 } & 3 & 5 & 5 & 5 & 4 & 4 & 4 & 3 & 3 & 2 \\
\hline
\end{tabular}

Note: 1. Very bad; 2. Bad; 3. Acceptable; 4. Good; 5. Very Good

Table-3: Results of Organoleptic Test in Mackerel (Smell)

\begin{tabular}{|c|c|c|c|c|c|c|c|c|c|c|}
\hline \multirow{2}{*}{$\begin{array}{l}\text { Pyrolysis } \\
\text { Temperature } \\
\left({ }^{\circ} \mathrm{C}\right)\end{array}$} & \multirow{2}{*}{$\begin{array}{c}\text { Liquid } \\
\text { Smoke } \\
\text { Conc.(\%) }\end{array}$} & \multicolumn{9}{|c|}{ Smell Change (hours) } \\
\hline & & 8 & 16 & 24 & 32 & 40 & 48 & 56 & 64 & 72 \\
\hline \multirow{4}{*}{300} & 0.5 & 5 & 5 & 4 & 4 & 3 & 2 & 1 & 1 & 1 \\
\hline & 1 & 5 & 5 & 4 & 4 & 3 & 2 & 2 & 1 & 1 \\
\hline & 2 & 5 & 5 & 4 & 3 & 3 & 3 & 2 & 1 & 1 \\
\hline & 3 & 5 & 5 & 4 & 4 & 3 & 3 & 2 & 2 & 1 \\
\hline \multirow{4}{*}{340} & 0.5 & 5 & 5 & 4 & 4 & 3 & 2 & 2 & 1 & 1 \\
\hline & 1 & 5 & 5 & 4 & 4 & 4 & 3 & 2 & 1 & 1 \\
\hline & 2 & 5 & 5 & 4 & 4 & 3 & 3 & 2 & 1 & 1 \\
\hline & 3 & 5 & 5 & 4 & 4 & 4 & 3 & 3 & 2 & 1 \\
\hline \multirow{4}{*}{380} & 0.5 & 5 & 5 & 4 & 4 & 3 & 3 & 2 & 2 & 1 \\
\hline & 1 & 5 & 5 & 4 & 4 & 4 & 3 & 2 & 2 & 1 \\
\hline & 2 & 5 & 5 & 4 & 4 & 4 & 3 & 2 & 2 & 1 \\
\hline & 3 & 5 & 5 & 5 & 4 & 4 & 3 & 2 & 2 & 2 \\
\hline
\end{tabular}

Note: 1. Very bad, 2. Bad, 3. Acceptable, 4. A little smell, 5. No smell

Table-4: Results of Organoleptic Test in Mackerel (Texture)

\begin{tabular}{|c|c|c|c|c|c|c|c|c|c|c|}
\hline \multirow{2}{*}{$\begin{array}{c}\text { Pyrolysis } \\
\text { Temperature } \\
\left({ }^{\circ} \mathrm{C}\right)\end{array}$} & \multirow{2}{*}{$\begin{array}{c}\text { Liquid } \\
\text { Smoke } \\
\text { Conc. (\%) }\end{array}$} & \multicolumn{9}{|c|}{ Texture Change (hours) } \\
\hline & & 8 & 16 & 24 & 32 & 40 & 48 & 56 & 64 & 72 \\
\hline \multirow{4}{*}{300} & 0.5 & 5 & 5 & 4 & 4 & 3 & 3 & 2 & 1 & 1 \\
\hline & 1 & 5 & 5 & 4 & 4 & 3 & 3 & 2 & 1 & 1 \\
\hline & 2 & 5 & 5 & 4 & 4 & 4 & 3 & 2 & 1 & 1 \\
\hline & 3 & 5 & 5 & 4 & 4 & 4 & 3 & 3 & 2 & 1 \\
\hline \multirow{4}{*}{340} & 0.5 & 5 & 5 & 4 & 4 & 3 & 2 & 2 & 1 & 1 \\
\hline & 1 & 5 & 5 & 4 & 4 & 3 & 3 & 2 & 1 & 1 \\
\hline & 2 & 5 & 5 & 5 & 4 & 4 & 3 & 3 & 2 & 1 \\
\hline & 3 & 5 & 5 & 5 & 4 & 4 & 4 & 3 & 2 & 2 \\
\hline \multirow{4}{*}{380} & 0.5 & 5 & 5 & 4 & 4 & 3 & 3 & 2 & 2 & 1 \\
\hline & 1 & 5 & 5 & 4 & 4 & 4 & 3 & 2 & 2 & 1 \\
\hline & 2 & 5 & 5 & 5 & 5 & 4 & 3 & 3 & 2 & 2 \\
\hline & 3 & 5 & 5 & 5 & 5 & 4 & 4 & 3 & 3 & 2 \\
\hline
\end{tabular}

Note: 1. Very soft, 2. Soft, 3. A little chewy, 4. Quite chewy, 5. Chewy

\section{CONCLUSION}

The results show that liquid smoke from oil palm kernel shell can be used as a preservative for mackerel. Higher liquid smoke concentration results in longer preservation, although longer soaking and higher concentration give the fish a smoky smell, rendering it less attractive for consumers. Mackerel preserved in $2 \%$ liquid smoke at a pyrolysis temperature of $380^{\circ} \mathrm{C}$ has a longer storage life at 64 hours, with a TVB value of $26.73 \mathrm{mgN}$. Without the addition of a preservative, mackerel only remains fresh for 24 hours before it can no longer be consumed because of its unacceptable smell, pale color, and visible decay, with a TVB value of $30.95 \mathrm{mgN}$. 
RASĀYAN $J$. Chem.

Vol. 11 | No. 3 |1120 - 1125 | July - September | 2018

\section{ACKNOWLEDGMENT}

The authors would like to acknowledge the Ministry of Research, Technology, and Higher Education of Indonesia for the research funding. Thanks also to Ms. Laili Nandriani for help in the data analysis in this study.

\section{REFERENCES}

1. R. Uddin, M.I. Wahid, T. Jasmeen, N.H. Huda and K.B. Sutradhar, S. J. Pharm. Sci., 4(1), 49(2011), DOI: $10.3329 /$ sjps.v4i1.8866

2. J.P. Girrad, Smoking, Technology of Meat and Meat Products, Ellis Horwood, New York, p. 165 (1992).

3. F. Sahena, I.S.M. Zaidul, S.Jinap, A.M. Yazid, A. Khatib and N.A.N. Norulaini, Food. Chem., 120(3), 879 (2010), DOI:10.1016/j.foodchem.2009.10.055

4. S. Metin, N. Erkan, C. Varlik and N. Aran, Eur. Food. Res. Technol., 213(3), 174 (2001), DOI: $10.1007 / \mathrm{s} 002170100362$

5. C.N. Wendakoon and M. Sakaguchi, J. Food Prot., 56(5) , 413(1993), DOI: 10.4315/0362-028X56.5.410

6. P. Viji, P.K. Binsi, S. Visnuvinayagam, J. Bindu, C.N. Ravishankar and T.K.S. Gopal, J. Food. Sci. Tech., 52(10) 6289 (2015), DOI: 10.1007/s13197-015-1788-1

7. A.E. Goulas and M.G. Kontominas, Food. Chem., 93(3) , 520 (2005), DOI: 10.1016/j.foodchem.2004.09.040

8. S. Metin, N. Erkan, C. Varlik and O. Ozden, Fisheries Sci., 68(1) , 214 (2002), DOI: 10.1046/j.14442906.2002.00410.x

9. İ. Uçak, Y. Özogul and M. Durmuş, Int. J. Food Sci. Tech., 46(6) , 1163 (2001), DOI: 10.1111/j.1365-2621.2011.02610.x

10. M. Faisal , A. Gani, Husni and H. Daimon, Int. J. GEOMATE., 13(37) , 147 (2017), DOI: 10.21660//2017.37.2734

11. M.D. Guillen and M.L. Ibargoitia, J. Agr. Food Chem., 46(4) , 1276 (1998), DOI: 10.1021/jf970952x

12. V. Varlet, T. Serot and C. Prost, Smoke flavoring technology in seafood. In Handbook of seafood and seafood products analysis. Boca Raton, FL: CRC Press, p. 233 (2010).

13. L.C. Doherty and M. A. Cohn, Seed. Sci. Res., 10, 415 (2000), DOI: 10.1017/S0960258500000465

14. M.D. Guillén and N. Cabo, Meat. Sci., 66 (3) , 647 (2004), DOI: 10.1016/S0309-1740(03)00185-2

15. S. Saloko, P. Darmadji, B. Setiaji and Y. Pranoto, Food Biosci., 7,71 (2014), DOI: 10.1016/j.fbio.2014.05.008

16. I. Zuraida, I. Sukarno and S. Budijanto, Int. Food Res. J., 18, 405 (2011).

17. M. Faisal, A. Gani, Husni, A. Baihaqi and H. Daimon, J. Eng. Appl. Sci., 11(12) , 2587 (2016), DOI: $10.3923 /$ jeasci.2016.2583.2587

18. M. Faisal and A. Gani, Int. J. GEOMATE., 15 (47), 145-150 (2018), DOI: 10.21660/2018.47.06109

19. M. Faisal, A.R.Yelvia Sunarti and H. Desvita, Rasayan J. Chem., 11(2), 871-876(2018), DOI: 10.7324/RJC.2018.1123035

20. M. Faisal, T. Chamzurni and H. Daimon, Int. J. GEOMATE., 14(43), 36 (2018), DOI: $10.21660 / 2018.43 .3531$

21. O.P. Fraser and S. Sumar, Nutr. Food Sci., 98, 325 (1998), DOI: 10.1108/00346659810235242

22. L. Farber, Freshness Tests. Fish as Food. Vol IV. New York: Academic Press Inc. (1965).

23. C. Karungi, Y.B. Byaruhanga and J.H. Muyonga, J. Food Chem., 85, 13 (2003), DOI: 10.1016/S0308-8146(03)00291-7

24. W. Fan, J. Sun, Y. Chen, J. Qiu, Y. Zhang and Y. Chi, Food Chem., 115(1) , 70 (2009), DOI: 10.1016/j.foodchem.2008.11.060

[RJC-2090/2018] 